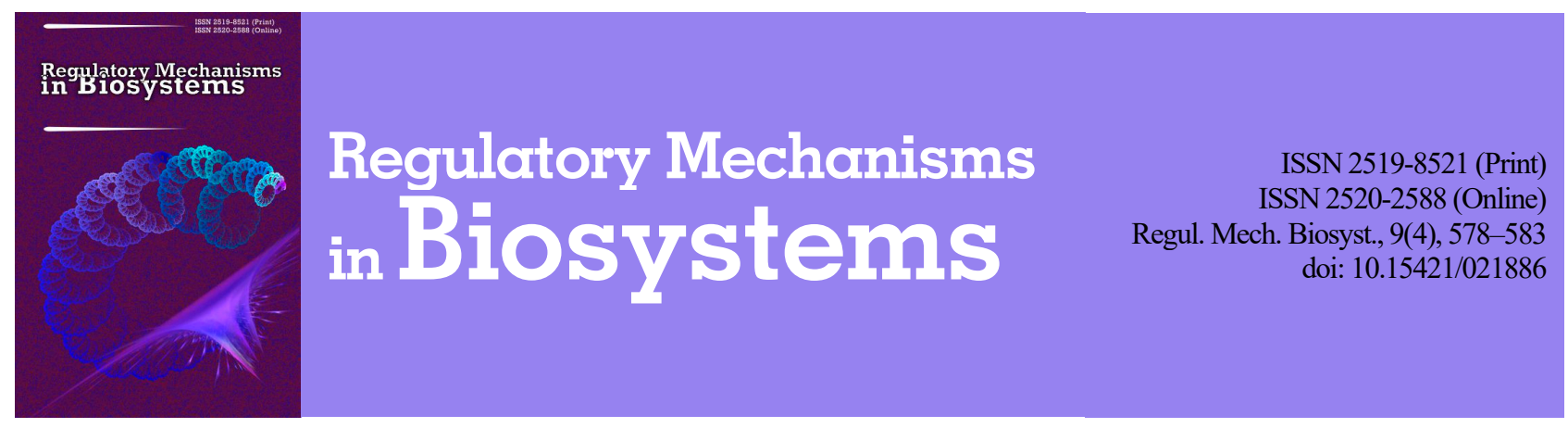

\title{
Differential species characters of Baruscapillaria anseris and B. obsignata nematodes obtained from the domestic goose
}

\author{
V. A. Yevstafieva*, V. I. Yeresko*, M. A. Pishchalenko*, L. V. Nagorna** \\ *Poltava State Agrarian Academy, Poltava, Ukraine \\ **Sumy National Agrarian University, Sumy, Ukraine
}

Article info

Received 15.10.2018

Received in revised form 10.11.2018

Accepted 13.11.2018

Poltava State Agrarian

Academy, Skovorody st., 1/3,

Poltava, 36003, Ukraine.

Tel.: +38-050-183-78-78.

E-mail:evstva@ukr.net

Sumy National Agrarian

University, G. Kondrateva st.

160, Sumy, 40021, Ukraine.

E-mail:lvn10@ukr.net

Yevstafieva, V. A., Yeresko, V. I., Pishchalenko, M. A., \& Nagorna, L. V. (2018). Differential species characters of Baruscapillaria anseris and B. obsignata nematodes obtained from the domestic goose. Regulatory Mechanisms in Biosystems, 9(4), 578-583. doi:10.15421/021886

The study presents species composition and abundance of nematodes of the family Capillariidae (Nematoda, Trichocephalida), parasitizing the domestic goose (Anser anser dom. Linnaeus, 1758) in Poltava region, Ukraine. Morphological specifics of adult specimens of collected helminths are examined and new data is obtained for species identification of Capillariidae considering their metric parameters. The pathogens of capillariasis in geese are represented by two species, Baruscapillaria anseris (Madsen, 1945) Moravec, 1982 and B. obsignata (Madsen, 1945) Moravec, 1982 with the former predominant. Prevalence of infection by $B$. anseris in domestic fowl was up to $46.8 \%$, the abundance index reached 17.9 specimens. The proportion of geese infected with $B$. obsignata was $23.9 \%$, and the abundance index was 3.8 specimens. Morphological study of the collected mature male and female nematodes revealed the significant similarity of both species in the general body structure and in identification characters: vulva and vagina structure in females, tail end, spicule and spicule sheath in males. Statistically significant differences were determined in the metric parameters of male and female $B$. anseris and B. obsignata nematodes. Those differences can be used to improve species identification. Males of $B$. anseris were larger than males of $B$. obsignata by 16 metric parameters including the length and width of body, spicule and spicule sheath, width of pseudobursa, and distance between the rays of pseudobursa. Females of $B$. anseris and B. obsignata were significantly different by seven metric parameters. By five parameters (length and width of various body regions) the $B$. anseris females were larger than $B$. obsignata. Metric parameters of the studied species are also of interest for taxonomic identification: the eggs of $B$. obsignata are longer and narrower than those of $B$. anseris.

Keywords: nematodes; Capillariidae; abundance indices, differential identification; morphology; metric parameters

\section{Introduction}

Nematodes of the family Capillariidae (Neveu-Lemaire, 1936) are numerous, common pathogenic roundworms. There are rather new revisions of known taxa and descriptions of new species (Butterworth \& Beverley-Burton, 1980; Moravec, 1982; Moravec et al., 2010). Species of this family are known to infect humans, wild and domestic animals, and fish (Robles Mdel et al., 2012; Iglesias et al., 2013; Khalifa \& Othman, 2014). Several species, such as Paracapillaria philippinensis (Syn.: Capillaria philippinensis) Chitwood, Velasquez and Salazar, 1968, Calodium hepaticum (Syn.: Capillaria hepatica) Bancroft, 1893, Pearsonema plica (Syn.: Capillaria plica) Rudolphi, 1819, and Eucoleus aerophilus (Syn.: Capillaria aerophila) Creplin, 1839 are highly pathogenic and of significant epizootic and epidemiological importance (Basso et al., 2014; El-Dib et al., 2015; Ochi et al., 2017; Kalinkin et al., 2018).

The ecological and faunistical studies of helminths in wild, synanthropic and domestic birds show that the Capillariidae nematodes are widely distributed and are important in the helminth faunistical complex. Domestic poultry are more likely to obtain capillariid worms in the case of outdoor rearing, in cross-infecting contacts with the wild or synanthropic birds parasitized with common nematode species (Jortner et al., 1967; Yoshino et al., 2009; Hoque et al., 2011; Dipineto et al., 2013). For example, in several regions of Germany, the prevalence of capillariid infection among wild ducks was $4.2 \%$. The infection was monospecific, caused by Capillaria anatis (Schrank, 1790) and its domination indices were higher than threshold value (Kavetska, 2005). The same species was collected from domestic goose in Poland with the prevalence of infection up to $33.5 \%$ (Kornaś et al., 2015). In Japan the capillariid species Pseudocapillaria mergi (Madsen, 1945) was recorded in seven species of Anseriformes (Nakamura \& Asakawa, 2001). The Capillaria spp. infected $21.7 \%$ of birds of Nigeria, and $5.33 \%$ domestic goose in India (Adejinmi \& Oke, 2011; Hamadani et al., 2017).

There are varying views on taxonomic importance of characters at the genus level of Capillariidae. All known revisions of the system of Capillariidae are based on the classification by Moravec (1982) according to which there are four genera parasitizing domestic waterfowl: Baruscapillaria (Moravec, 1982), Aonchotheca (López-Neyra, 1947), Capillaria (Zeder, 1800), and Eucoleus (Dujardin, 1845). In particular, Aonchotheca caudinflata (Molin, 1858) should be considered a nonspecific parasite of waterfowl (Skrjabin et al., 1957; Ryzhikov, 1967).

The results of morphological studies are important in practical taxonomy for constructing the natural system of the nematode group in question, and for understanding the evolution and phylogeny of Capillariidae. The general view of the structure and anatomic organization of these nematodes are based on such studies. The latter is significant in understanding the morpho-functional specifics of capillariids (Moravec et al., 1987; Stapf et al., 2013; Tanveer et al., 2015). In long-term studies, the following morphological characters have been suggested for species identification of Capillariidae: the structure of male tail end, the ornamentation of spicule sheath, the numbers and shape of stichocytes, the shape and size of eggs, egg surface specifics, and the vulval area structure, location and biological features (Zd'árská \& Nebesárová, 2000; Frantová, 
2001; Traversa et al., 2011). The metric characteristics of helminths also matter in enhancing the effectiveness of their species identification (Kajerová \& Baruš, 2005; D'ávila et al., 2012; Yevstafyeva et al., 2017).

Thus, capillariids are incredibly interesting, in many ways they are a unique group of parasitic nematodes. By the number of species they are the most abundant group of the order Trichocephalida. Certain species which are of epidemiologic and epizootic importance, parasitizing in humans, wild and domestic mammals, are described in detail in scientific reports. In contrast, there are many under-researched problems of morphology, fauna and differential diagnostics of Capillariidae parasites of domestic goose.

The present study aimed to review the representatives of the family Capillariidae, parasitizing domestic goose in Ukraine, and to determine the differential morphologic and metric characters of mature males and females of the collected capillariid species.

\section{Materials and methods}

Species identification, study of abundance and parasitological analysis of nematodes of the family Capillariidae were conducted in 20162018. The helminths were collected during helminthological investigation of the intestine of 417 domestic geese (Skrjabyn, 1928) at farms in Poltava region. The roundworms were identified according to (Skriabyn et al., 1957; Ryzhikov, 1967). The population parameters included occurrence index, abundance index and intensity of infection. In morphological analysis, 7,460 specimens of the species $B$. anseris (2,199 males and 5,261 females) and 1,566 specimens of the species B. obsignata (428 males and 1,138 females) were used.

To measure metric characteristics of the adult capillariid nematodes, ImageJ for Windows ${ }^{\circledR}$ (version 2.00) software was used in interactive mode using $5^{\times}, 10^{\times}, 40^{\times}$objective and $10^{\times}$photo eyepiece. To calibrate the image analyzer, ruled scale of ocular micrometer was coincided with the scale of stage micrometer included in MikroMed microscope kit. Microphotographs were taken using a digital camera of MikroMed (China) microscope.

Statistical processing of the experimental results were calculated using standard deviation (SD) and average values (x). Significance of difference between average values in the studied groups of nematodes was determined using one-way analysis of variance and F-test for $95 \%$ confidence level.

\section{Results}

Nematodes of the family Capillariidae are common in domestic geese in Poltava region of Ukraine. They are represented by two species, Baruscapillaria anseris (Madsen, 1945) Moravec, 1982 and B. obsignata (Madsen, 1945) Moravec, 1982. The dominant species is B. anseris, with average infection rates up to $46.8 \%$ of domestic geese, abundance index 17.9 specimens per host, and average intensity of infection up to 38.3 specimens per host (from 2 to 168 specimens). The abundance of $B . o b-$ signata is lower than that of $B$. anseris. The prevalence of infection with B. obsignata is $23.9 \%$, abundance index 3.8 specimens, and average intensity of infection up to 15.7 specimens per host (from 2 to 57 specimens per host).

Nematodes of the species $B$. anseris and B. obsignata are morphologically very similar and their body structure is typical for capillariids. They are parasites with slender, thin, slightly translucent filiform body that gradually tapers to the tail end (Fig. 1a). The cuticle is with fine transverse striation. The head end is tapered; the mouth is very small and lacks ornamentation (Fig. 1b). Esophagus length is almost half of the body. The anterior part of the esophagus is thin and muscled. The posterior part of the esophagus is surrounded by a longitudinally elongated row of well-defined cells (stichocytes). The esophagus is immersed in stichocytes which cover it dorsally and laterally. There also are well-defined and relatively wide bacillary bands.

The morphological study of male and female specimens of $B$. anseris and $B$. obsignata revealed that their species-specific characters are also quite similar. For example, males have one rather long spicule, covered by spicule sheath with transverse striation. The cuticle lacks spikes and has folds. The distal end of spicule is tapered and rounded. Proximal end spicule is funnel-shaped with wavy edges. The tail bursa is a pseudobursa without lobes, it has rounded rays at each side. The rays support the pseudobursa membrane (Fig. 2).

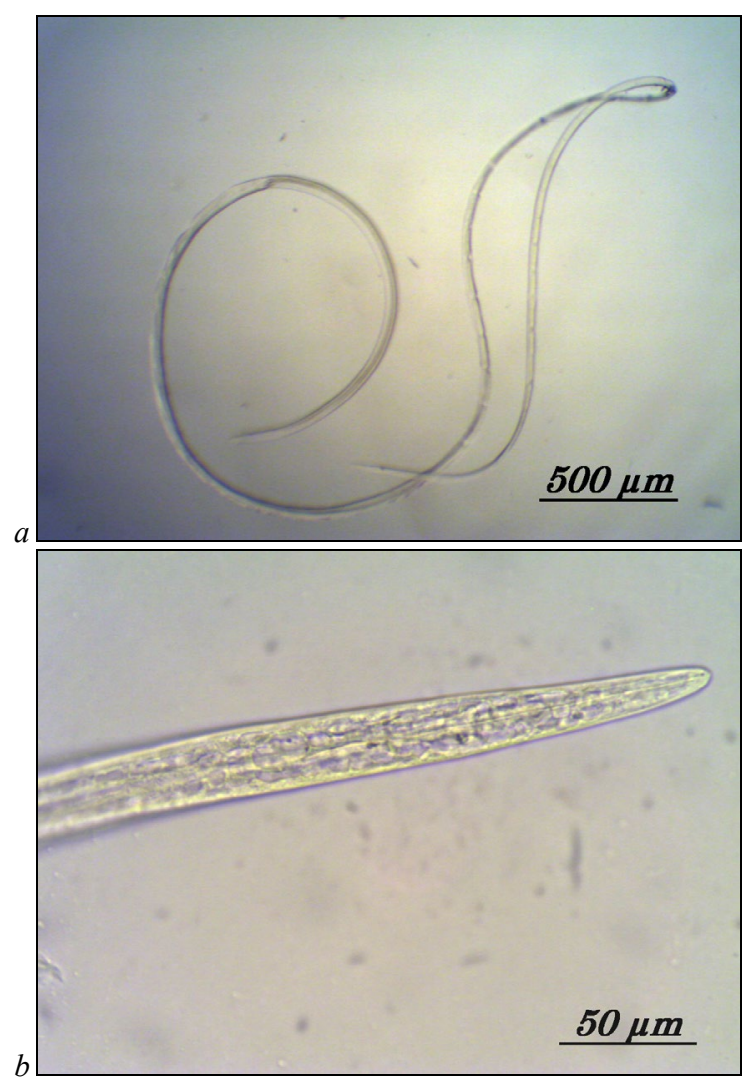

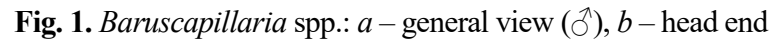

Male $B$. obsignata specimens also have one spicule covered by a spicule sheath without spikes. The surface of the spicule sheath is significantly folded and resembles corrugation. The distal end of the spicule is tapered and rounded similarly to $B$. anseris males. The proximal end of the spicule is widened like horn, its edges have a folded fringe. The pseudobursa is translucent a cuticular membrane supported at both sides by two rays which are wide and round at base (Fig. 3).

The vulva of $B$. anseris females opens posterior to the end of the esophagus. There is no vulval valve at the vulval area; instead there is an almost invisible slightly defined cuticular lip. The vagina has a well-defined muscular wall. The uterus has long loops filled with characteristic barrel-shaped eggs with seemingly pressed-in plugs. Mostly due to the thin nematode body, the eggs are arranged in a single row (Fig. 4).

Morphologically, the vulva in $B$. obsignata female specimens opens near the transition of the esophagus to the intestine. The vulva is slit-shaped. The cuticular lip in the vulva area is more protruding at the body surface than that of $B$. anseris females. The vagina of $B$. obsignata females is directed backward, muscular, straight or with a slight bend; the uterus is filled with eggs typical of Capillariidae (barrel-shaped, oval with thin shell and two translucent plugs at ends) (Fig. 5).

The comparison of metric parameters of $B$. anseris and B. obsignata nematodes revealed statistically significant differences that can be used to enhance species identification. For males of both species, morphometric differences are found in 17 parameters. By 16 of those, B. anseris males were larger (Table 1 ).

Males of $B$. anseris were longer by $8.9 \%(10.90 \pm 1.59 \mu \mathrm{m}, \mathrm{P}<0.05)$ than males of $B$. obsignata $(9.93 \pm 0.86 \mu \mathrm{m})$. The width of $B$. anseris specimens in different parts of the body (head end, esophagus end, posterior third of the body, pseudobursa base at the tail end) were 8.6$17.7 \%$ larger $(\mathrm{P}<0.05)$ compared with $B$. obsignata. The sizes of the spicule and spicule sheath were significantly different in the compared species. In $B$. anseris the spicule was longer (by $22.9 \%, \mathrm{P}<0.05$ ) and wider throughout its length (by $15.0-24.5 \%, \mathrm{P}<0.05$ ) than in $B$. obsignata. 


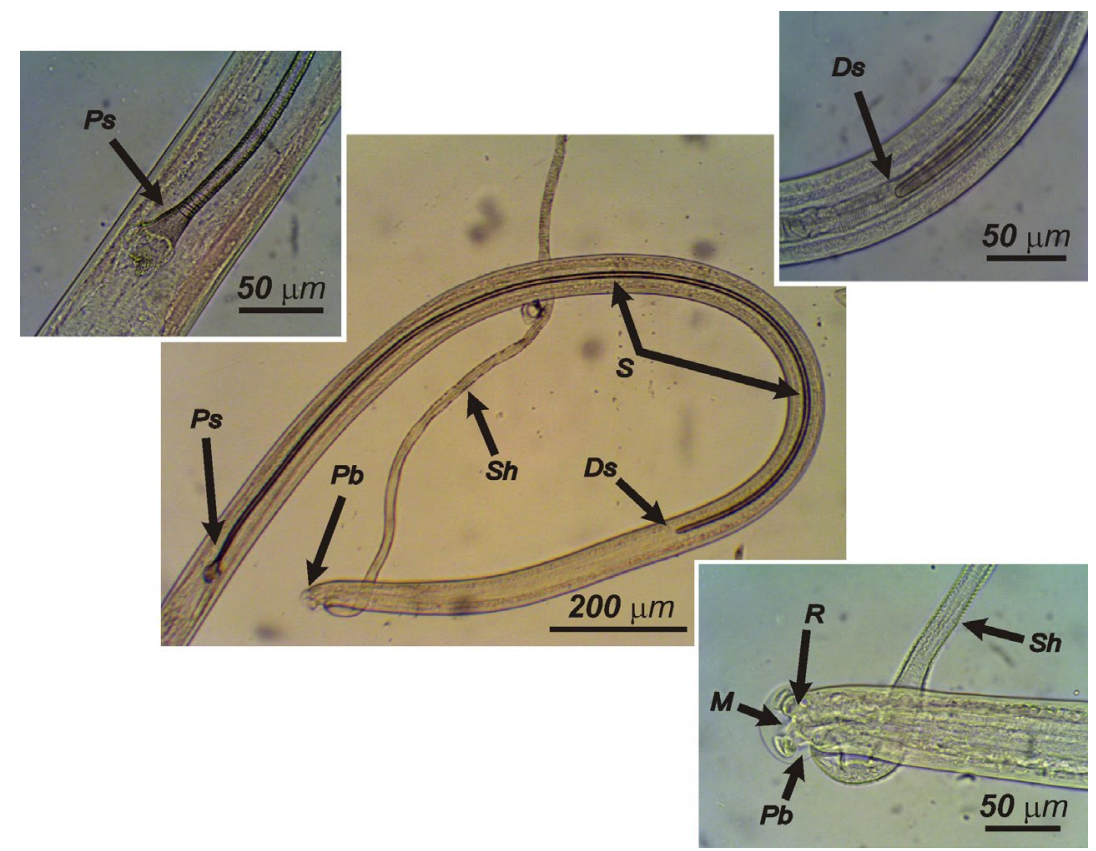

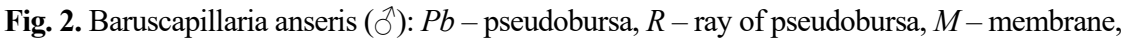
$S h$ - extruded spicule sheath, $S$ - spicule, $P s$ - proximal end of spicule, $D s$ - distal end of spicule

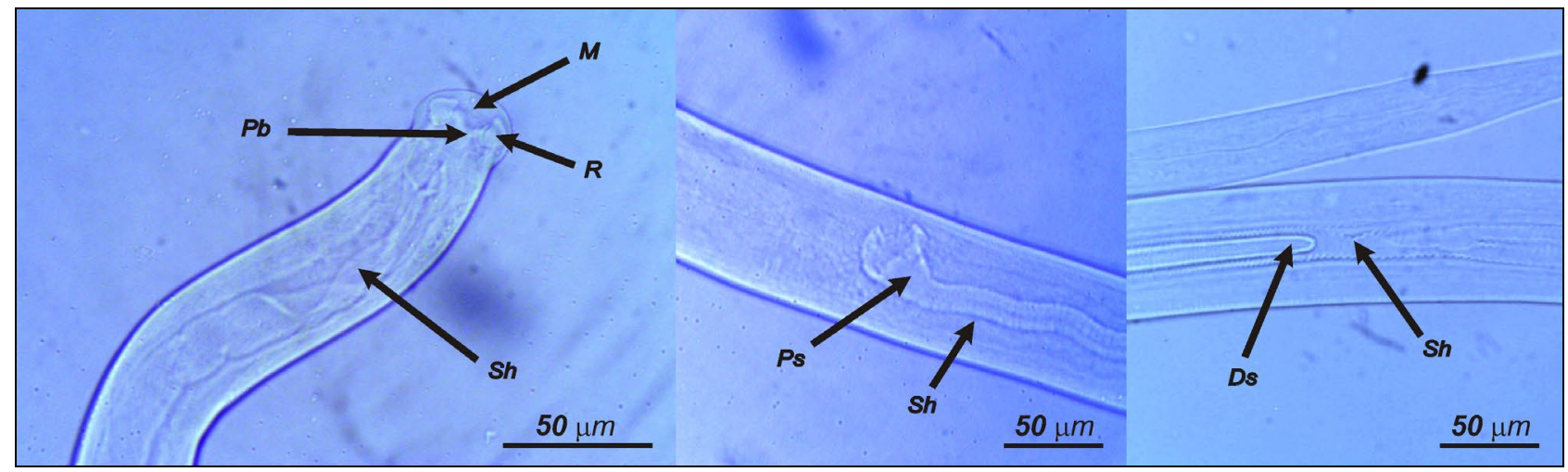

Fig. 3. Baruscapillaria obsignata ( $\left.{ }^{\Uparrow}\right)$ : $P b$ - pseudobursa, $R$ - ray of pseudobursa, $M$-membrane, $S h$ - extruded spicule sheath, $S$ - spicule, $P S$ - proximal end of spicule, $D s-$ distal end of spicule

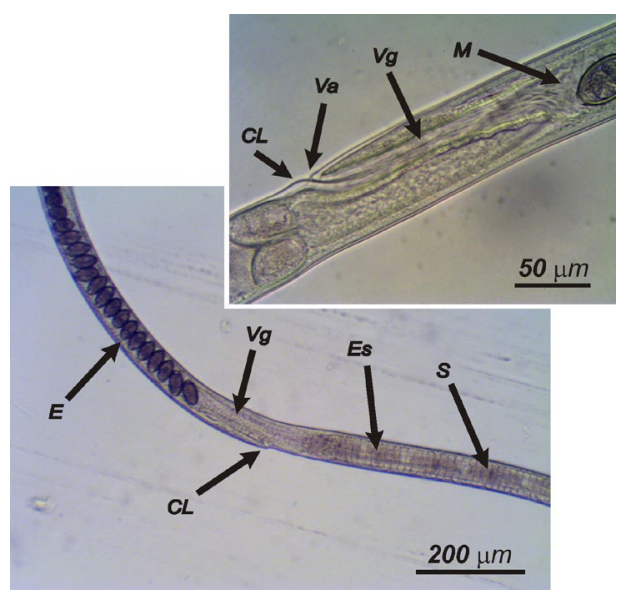

Fig. 4. Baruscapillaria anseris (): $C L-$ cuticular lip, $V a$ - vulva area, $V g$ - vagina, $U$ - uterus, $E$ - eggs, $E s$ - esophagus, $S$ - stichocytes

Similar data were obtained when comparing the metric values of the length and width of the spicule sheath. It was longer (by $14.1 \%, \mathrm{P}<0.05$ ) and wider (by $12.5-17.0 \%, \mathrm{P}<0.05$ ) in $B$. anseris specimens. The obtained data on the size of pseudobursa in the studied nematode species indicate the possibility of using this character in their identification.
The pseudobursa of $B$. anseris was significantly $(\mathrm{P}<0.05)$ shorter (by $6.5 \%$ ), and wider (by $16.3 \%$ ) compared with that of $B$. obsignata. Hence, the ratio of length to width of pseudobursa was larger in $B$. anseris by $21.3 \%(\mathrm{P}<0.05)$. The distance between the ray ends and the pseudobursa was also longer (by $11.6 \%, \mathrm{P}<0.05$ ) in $B$. anseris.

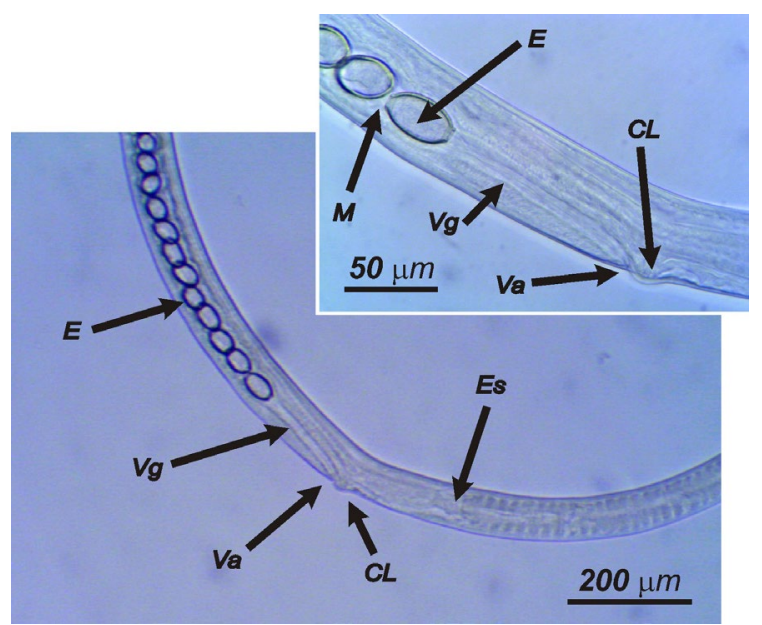

Fig. 5. Baruscapillaria obsignata $(+)$ : $C L-$ cuticular lip, $V a$ - vulva area, $V g$ - vagina, $U$ - uterus, $E$ - eggs, $E s$ - esophagus 
Table 1

Metric parameters of $\delta$ nematodes of the genus Baruscapillaria, obtained from domestic geese $(n=20)$

\begin{tabular}{|c|c|c|c|c|}
\hline \multirow{2}{*}{ Parameters } & \multicolumn{2}{|c|}{ Baruscapillaria anseris } & \multicolumn{2}{|c|}{ Baruscapillaria obsignata } \\
\hline & $\mathrm{x} \pm \mathrm{SD}$ & Min-Max & $\mathrm{x} \pm \mathrm{SD}$ & Min-Max \\
\hline Length of body, mm & $10.90 \pm 1.59$ & $8.00-14.00$ & $9.93 \pm 0.86^{*}$ & $8.50-11.50$ \\
\hline & & & & \\
\hline - head end, $\mu \mathrm{r}$ & $7.95 \pm 1.26$ & $6.12-9.85$ & $6.54 \pm 0.50 *$ & $5.84-7.85$ \\
\hline - esophagus end, $\mu \mathrm{m}$ & $\begin{array}{c}47.16 \pm \\
2.03\end{array}$ & $\begin{array}{c}42.96- \\
50.02\end{array}$ & $\begin{array}{c}43.12 \pm \\
2.01^{*}\end{array}$ & $\begin{array}{c}40.68- \\
48.08\end{array}$ \\
\hline - posterior third of body, $\mu \mathrm{m}$ & $\begin{array}{l}52.34 \pm \\
2.21\end{array}$ & $\begin{array}{c}48.62- \\
56.39\end{array}$ & $\begin{array}{l}44.36 \pm \\
2.03^{*}\end{array}$ & $\begin{array}{c}41.66- \\
48.95\end{array}$ \\
\hline - pseudobursa base, $\mu \mathrm{m}$ & $\begin{array}{c}31.38 \pm \\
1.02\end{array}$ & $\begin{array}{c}29.07- \\
33.15\end{array}$ & $\begin{array}{c}26.62 \pm \\
0.65^{*}\end{array}$ & $\begin{array}{c}25.34- \\
27.83\end{array}$ \\
\hline Esophagus length, mm & $5.13 \pm 0.25$ & $4.79-5.63$ & $4.48 \pm 0.45$ & $3.87-5.34$ \\
\hline $\begin{array}{l}\text { Length of spicule, } \mathrm{mm} \\
\text { Width of spicule at: }\end{array}$ & $1.61 \pm$ & $4-1.80$ & $1.24 \pm 0.07^{*}$ & $1.12-1.34$ \\
\hline - proximal end, $\mu \mathrm{m}$ & $\begin{array}{r}24.7 \\
1.9\end{array}$ & $\begin{array}{l}20.65- \\
27.68\end{array}$ & $\begin{array}{l}80 \pm \\
90^{*}\end{array}$ & $\begin{array}{l}16.36- \\
22.69\end{array}$ \\
\hline - base of funnel-like & $11.80 \pm$ & $11.05-$ & $9.19 \pm$ & $8.18-$ \\
\hline dilatatio & 0.30 & 12.08 & $0.76^{*}$ & 10.48 \\
\hline - the middle, $\mu \mathrm{m}$ & $9.29 \pm 0.71$ & $8.17-10.31$ & $7.01 \pm$ & $6.45-7.64$ \\
\hline - distal end, $\mu \mathrm{m}$ & $6.73 \pm 0$ & $6.03-7.33$ & $5.72 \pm 0$ & -6.14 \\
\hline Length of spic & $1.85 \pm 0$ & $1.74-2.00$ & $1.59 \pm 0$ & -1.69 \\
\hline $\begin{array}{l}\text { Width of spicule sheath at } \\
\text { proximal spicule end, } \mu \mathrm{m}\end{array}$ & $\begin{array}{c}25.04 \pm \\
1.85\end{array}$ & $\begin{array}{c}21.08- \\
27.54\end{array}$ & $\begin{array}{c}21.91 \pm \\
1.67^{*}\end{array}$ & $\begin{array}{c}18.00- \\
24.68\end{array}$ \\
\hline $\begin{array}{l}\text { Width of spicule sheath at } \\
\text { distal spicule end, } \mu \mathrm{m}\end{array}$ & $\begin{array}{c}11.79 \pm \\
0.82\end{array}$ & $\begin{array}{c}10.28- \\
13.02\end{array}$ & $\begin{array}{l}9.78 \pm \\
1.56^{*}\end{array}$ & $\begin{array}{l}8.01- \\
17.68\end{array}$ \\
\hline Length of pseudobursa, $\mu \mathrm{m}$ & $\begin{array}{c}19.88 \pm \\
1.27\end{array}$ & $\begin{array}{l}17.84- \\
22.38\end{array}$ & $\begin{array}{c}21.26 \pm \\
1.69^{*}\end{array}$ & $\begin{array}{l}18.63- \\
23.84\end{array}$ \\
\hline Width of pseudobursa, $\mu \mathrm{m}$ & $\begin{array}{c}39.94 \pm \\
3.59\end{array}$ & $\begin{array}{c}34.69- \\
46.55\end{array}$ & $\begin{array}{l}33.44 \pm \\
2.25^{*}\end{array}$ & $\begin{array}{c}30.09- \\
37.64\end{array}$ \\
\hline $\begin{array}{l}\text { Length to width of } \\
\text { pseudobursa ratio }\end{array}$ & $1: 2.02$ & $\begin{array}{l}1: 1.65- \\
1: 2.45\end{array}$ & $1: 1.59^{*}$ & $\begin{array}{l}1: 1.28- \\
1: 1.96\end{array}$ \\
\hline $\begin{array}{l}\text { Distance between ray ends, } \\
\mu \mathrm{m}\end{array}$ & $\begin{array}{c}12.68 \pm \\
0.82\end{array}$ & $\begin{array}{c}11.08- \\
13.86\end{array}$ & $\begin{array}{c}11.21 \pm \\
0.97^{*}\end{array}$ & $\begin{array}{l}9.08- \\
12.30\end{array}$ \\
\hline
\end{tabular}

Note: $*-\mathrm{P}<0.05$ compared to the values of parameters of $B$. anseris.

When comparing the $B$. anseris and $B$. obsignata females by 10 metric parameters, it was determined that there is a significant difference by six parameters (Table 2$)$.

Table 2

Metric parameters $q$ nematodes of the genus Baruscapillaria, obtained from domestic geese $(n=20)$

\begin{tabular}{|c|c|c|c|c|}
\hline \multirow{2}{*}{ Parameters } & \multicolumn{2}{|c|}{ Baruscapillaria anseris } & \multicolumn{2}{|c|}{ Baruscapillaria obsignata } \\
\hline & $\mathrm{x} \pm \mathrm{SD}$ & Min-Max & $\mathrm{x} \pm \mathrm{SD}$ & Min-Max \\
\hline Length of body, mm & $16.92 \pm 0.74$ & $15.00-17.50$ & $12.78 \pm 0.75^{*}$ & $11.50-14.00$ \\
\hline Width of body at: & & & & \\
\hline - head end, $\mu \mathrm{m}$ & $10.21 \pm 0.83$ & $8.32-11.24$ & $9.02 \pm 0.49 *$ & $8.33-10.11$ \\
\hline - esophagus end, $\mu \mathrm{m}$ & $70.87 \pm 2.91$ & $65.15-75.36$ & $48.17 \pm 2.86^{*}$ & 41.98 \\
\hline - vulva, $\mu \mathrm{m}$ & $68.90 \pm 2.92$ & $62.14-73.33$ & $46.74 \pm 3.24 *$ & $40.36-51.13$ \\
\hline - anus, $\mu \mathrm{m}$ & $31.53 \pm 3.20$ & $28.36-38.45$ & $29.72 \pm 1.49 *$ & $27.08-32.84$ \\
\hline $\begin{array}{l}\text { Length of esophagus, } \\
\mathrm{mm}\end{array}$ & $5.06 \pm 0.21$ & $4.58-5.39$ & $5.52 \pm 0.57^{*}$ & $4.19-6.34$ \\
\hline $\begin{array}{l}\text { Distance from esophagus } \\
\text { end to vulva, } \mu \mathrm{m}\end{array}$ & $83.21 \pm 7.94$ & $70.25-92.44$ & $79.38 \pm 10.48$ & $62.04-92.33$ \\
\hline $\begin{array}{l}\text { Length of cuticular lip, } \\
\mu \mathrm{m}\end{array}$ & $12.85 \pm 1.49$ & $10.18-15.20$ & $23.16 \pm 2.00$ & $20.36-27.12$ \\
\hline $\begin{array}{l}\text { Height of cuticular lip, } \\
\mu \mathrm{m}\end{array}$ & $3.38 \pm 0.32$ & $2.98-3.87$ & $5.21 \pm 1.05$ & $4.08-7.75$ \\
\hline $\begin{array}{l}\text { Ratio of height to length } \\
\text { of cuticular lip }\end{array}$ & $1: 3.85$ & $: 2.63-1: 4.9$ & $1: 4.57^{*}$ & $: 3.27-1: 6.2$ \\
\hline $\begin{array}{l}\text { Total length of egg with } \\
\text { plugs, } \mu \mathrm{m}\end{array}$ & $48.93 \pm 2.15$ & $40.21-50.54$ & $50.29 \pm 0.99 *$ & $48.22-52.33$ \\
\hline $\begin{array}{l}\text { Length of eggs without } \\
\text { plugs, } \mu \mathrm{m}\end{array}$ & $36.20 \pm 1.93$ & $32.33-40.21$ & $41.04 \pm 2.10$ & $36.25-45.12$ \\
\hline Egg width, $\mu \mathrm{m}$ & $27.94 \pm 1.91$ & $24.56-30.54$ & $25.95 \pm 0.98 *$ & $24.36-27.63$ \\
\hline Eggshell thickness, $\mu \mathrm{m}$ & $3.18 \pm 0.43$ & $2.64-3.98$ & $2.19 \pm 0.37$ & $1.66-2.98$ \\
\hline
\end{tabular}

Note: ${ }^{*}-\mathrm{P}<0.05$ compared to the values of parameters of $B$. anseris.

Therefore, female $B$. anseris nematodes were larger than $B$. obsignata females by five parameters. In contrast, $B$. obsignata females were larger compared to $B$. anseris females only by two parameters. It is determined that the $B$. anseris nematodes are longer by $24.5 \%$ (16.92 \pm
$0.74 \mathrm{~mm}, \mathrm{P}<0.05)$ and wider by $5.7-32.2 \%(10.21-70.87 \mu \mathrm{m})$ than females of $B$. obsignata (which are, correspondingly, $12.78 \pm 0.75 \mathrm{~mm}$ and 9.02-48.17 $\mu \mathrm{m}$ ). The height and length of cuticular lip in the vulva area were not statistically different in the studied species. However, the ratio of those parameters was higher in $B$. obsignata than in $B$. anseris (by $2.7 \%, \mathrm{P}<0.05$ ). There were no significant differences in the length of esophagus in males of the compared species. At the same time, the length of esophagus in B. obsignata females was longer by $8.3 \%(\mathrm{P}<$ 0.05 ), which can be used in identification of female specimens.

We studied the possibility of using morphometric parameters of eggs from uteri of $B$. anseris and $B$. obsignata females as a taxonomic characteristic. It was determined that there were significant differences $(\mathrm{P}$ $<0.05$ ) by two parameters. The eggs of $B$. anseris were shorter by $2.7 \%$ and wider by $7.1 \%$ than the eggs of $B$. obsignata. According to these data, the metric differences allow better identification of $B$. anseris and B. obsignata nematodes despite their morphological similarity.

\section{Discussion}

According to the present study, nematodes of the family Capillariidae which parasitize domestic geese are common in Poltava region of Ukraine. There are two capillariid species, B. anseris and B. obsignata. The most prevalent species is $B$. anseris, based on the high values of abundance indices in poultry. The prevalence of this infection is $48.6 \%$, intensity of infection and abundance index are up to 168 and 17.9 specimens respectively. The species $B$. obsignata is less common in domestic geese. Its prevalence is $23.9 \%$, the abundance index 3.8 specimens and maximum intensity of infection does not exceed 57 specimens per host. According to scientific reports, capillariids are common in wild, synanthropic and domestic aquatic and terrestrial birds (Adejinmi \& Oke, 2011; Nakamura \& Asakawa, 2001; Gürler et al., 2012; Hamadani et al., 2017). According to the current system of capillariids, there are three nematode species most specific to the domestic waterfowl, particularly the domestic goose (Anser anser dom.): Baruscapillaria anseris, Capillaria anatis (Schrank, 1790), Eucoleus contortus (Creplin, 1839) (Skrjabin et al., 1957; Ryzhikov, 1967; Moravec, 1982). For example, there are two species of capillariids in domestic waterfowl of 17 countries of Europe, $C$. anatis and E. contortus (Gibson et al., 2014). However there are also reports of non-specific infections in goose, such as Aonchotheca caudinflata (Molin, 1858) and B. obsignata. These species are most common and widely distributed in terrestrial birds, including chickens, and can cross-infect goose in case of common housing (Skrjabin et al., 1957; Ryzhikov, 1967; Barus et al., 1977; Busta, 1980). Our results support the notion that $B$. anseris is more adapted to geese, while $B$. obsignata is recorded from geese housed with chickens. Hence it is possible to conclude that the latter species is gradually adapting to a new host, the domestic goose, which is supported by low abundance indices.

The morphological study of $B$. anseris and B. obsignata specimens revealed their significant similarity. Their body structure is that typical of Capillariidae nematodes: thin filiform body, presence of bacillary bands, stichocytes in the esophagus area, and absence of any ornamentation at the head end (Skrjabin et al., 1957; Wakelin, 1966; Tamaru et al., 2015). The collected specimens belong to the genus Baruscapillaria, hence males of both species have tail ends with similar pseudobursae which lack lateral wings and consist of membrane and a pair of rays. The spicule is single, covered by a spicule sheath that lacks spikes. The collected females have slit-like vulvas, there are small cuticular lips. Most authors report the morphological diversity of Capillariidae nematodes, and note the morphological similarity of several species and incomplete data on their morphometry. The latter issue is essential in many difficulties of understanding capillariid phylogeny (Moravec, 1982; Moravec et al., 1987).

We conducted the first comparative analysis in Ukraine of morphometric parameters in male and female nematodes of the species $B$. anseris and $B$. obsignata obtained from the domestic goose. Distinctive characteristics are identified that can be useful in improving the effectiveness of the differential identification of these species. Thus, significant morphometric differences were determined by 17 parameters in $B$. anseris and $B$. obsignata males, and $B$. anseris males are larger than those of B. obsignata by 16 of those parameters. These parameters include the 
length and width in different parts of the body, the length, width of the spicule and spicule sheath. The sizes of pseudobursae are of interest: in $B$. anseris it is wider and shorter than in B. obsignata. This is supported by the ratio of length to width of pseudobursa and by the distance between the ray ends. At the same time, females of $B$. anseris and B. obsignata differ by seven parameters. By five of those parameters which include the length and width in different body areas, $B$. anseris females are larger than those of $B$. obsignata. We also note that the size of cuticular lip in the vulva area cannot be used as a differential character because of its variability. Our data is in line with findings of other authors (Yevstafyeva et al., 2017). The majority of studies indicate the important value of metric parameters as additional identification characters of various capillariid species (Kajerová \& Baruš, 2005; Dar et al., 2013).

The need to study the structure and metric parameters of eggs as criteria for the identification of capillary species is shown by the work of many authors (Campbell et al., 1991; Traversa et al., 2011). Therefore, we examined the metric parameters of eggs of the collected capillariid species in order to study the possibility of using them in the taxonomic identification of $B$. anseris and $B$. obsignata. A reliable difference in individual parameters of eggs was determined( $\mathrm{P}<0.05)$. Hence, $B$. anseris eggs were shorter and wider than $B$. obsignata eggs. The obtained results add to the data on the fauna and adaptation of capillariids in domestic goose, and also greatly facilitate the species identification of $B$. anseris and B. obsignata.

\section{Conclusion}

It is determined that capillariasis is a common infection of the domestic goose in the Poltava region of Ukraine. The fauna is represented by two species, the dominant of which is $B$. anseris. The proportion of geese by this species reached $46.8 \%$, the abundance index was 17.9 specimens per bird. B. obsignata was less common. Its abundance was low: prevalence $23.9 \%$, abundance index 3.8 specimens per host. The morphological structure in both species has a significant similarity in both males and females, which can make it difficult to identify them. To enhance the differential identification of $B$. anseris and $B$. obsignata species, it is necessary to take into account the metric parameters of their mature and embryonic developmental stages. Seventeen morphometric parameters are found in males of these capillariid species, 16 of which have significantly higher values in $B$. anseris. For the species identification of $B$. anseris and $B$. obsignata females, seven morphometric parameters are proposed, five of which, as in males, have significantly higher values in $B$. anseris. The metric characterristics of capillary eggs can also be used in comparison and taxonomic assessment of those nematodes. It is determined that in two parameters the embryonic stages of development of the compared species have signifycant differences: the eggs of $B$. anseris are shorter and wider than the eggs of B. obsignata.

\section{References}

Adejinmi, J. O., \& Oke, M. (2011). Gastro-intestinal parasites of domestic ducks (Anas platyrhynchos) in Ibadan Southwestern Nigeria. Asian Journal of Poultry Science, 5, 46-50.

Barus, V., Mikoásek, A., \& Busta, J. (1977). Influence of breeding technology of helminth fauna of geese (Anser anser f. domestica). Folia Parasitologica, 24(4), 305-314.

Basso, W., Spänhauer, Z., Arnold, S., \& Deplazes, P. (2014). Capillaria plica (syn. Pearsonema plica) infection in a dog with chronic pollakiuria: Challenges in the diagnosis and treatment. Parasitology International, 63(1), 140-142.

Busta, J. (1980). Helminths in broiler geese fattened in runs. Veterinarni Medicina, 25(12), 717-723.

Butterworth, E. W., \& Beverley-Burton, M. (1980). The taxonomy of Capillaria spp. (Nematoda: Trichuroidea) in carnivorous mammals from Ontario, Canada. Systematic Parasitology, 1(3-4), 211-236.

Campbell, B. G., \& Little, M. D. (1991). Identification of the eggs of a nematode (Eucoleus boehmi) from the nasal mucosa of North American dogs. Journal of the American Veterinary Medical Association, 198, 1520-1523.

Dar, J. A., Tanveer, S., Dar, S. A., \& Kuchai, J. A. (2013). First report of Capillaria anatis (Nematoda: Capillariidae) from Corvus species of Kashmir-India. Global Veterinaria, 10(4), 467-471.

D'ávila, S., Bessa, E. C. A., Souza-Lima, S., \& Rodrigues, M. L. A. (2012). Biased sex ratio and niche restriction in Baruscapillaria obsignata (Madsen 1945)
(Nematoda, Capillariidae) from Columba livia (Aves, Columbidae). Journal of Helminthology, 86(4), 401-405.

Dipineto, L., Borrelli, L., Pepe, P., Fioretti, A., Caputo, V., Cringoli, G., \& Rinaldi, L. (2013). Synanthropic birds and parasites. Avian Diseases, 57(4), 756-758.

El-Dib, N. A., El-Badry, A. A., Ta-Tang, T. H., \& Rubio, J. M. (2015). Molecular detection of Capillaria philippinensis: An emerging zoonosis in Egypt. Experimental Parasitology, 154, 127-133.

Frantová, D. (2001). Capillariid nematodes (Nematoda: Capillariidae) parasitic in the common cormorant (Phalacrocorax carbo), with redescription of Baruscapillaria carbonis (Dubinin et Dubinina, 1940). Folia Parasitologica, 48(3), 225-230.

Gibson, D., Bray, R., Hunt, D., Georgiev, B., Scholz, T., Harris, P., Bakke, T., Pojmanska, T., Niewiadomska, K., Kostadinova, A., Tkach, V., Bain, O., DuretteDesset, M., Gibbons, L., Moravec, F., Petter, A., Dimitrova, Z., Buchmann, K., Valtonen, E., \& de Jong, Y. (2014). Fauna Europaea: Helminths (animal parasitic). Biodiversity Data Journal, 2, e1060.

Gürler, A. T., Bölükbaş, C. S., Pekmezci, G. Z., Umur, Ş., \& Açici, M. (2012). Samsun'da Sülünlerde (Phasianus colchicus) Nekropsi ve Dışkı Bakısında Saptanan Helmintler. Türkiye Parazitoloji Dergisi, 36, 222-722.

Hamadani, H., Khan, A. A., Wani, Z. A., Jalal, H., Bihaqi, S. J. A., \& Mir, M. S. (2017). Parasitic profile of domestic geese of Kashmir. International Journal of Livestock Research, 7(5), 129-133.

Hoque, M. A., Skerratt, L. F., Rahman, M. A., Alim, M. A., Grace, D., Gummow, B., Rabiul Alam Beg, A. B., \& Debnath, N. C. (2011). Monitoring the health and production of household Jinding ducks on Hatia Island of Bangladesh. Tropical Animal Health and Production, 43(2), 431-440.

Iglesias, R., Centeno, L., García, N., \& García-Estévez, J. M. (2013). Pseudocapillaria (Pseudocapillaria) moraveci sp. n. (Nematoda: Capillariidae) from the stomach of Gobius paganellus (Perciformes: Gobiidae) from Vigo estuary (NW Spain). Folia Parasitologica, 60(2), 135-140.

Jortner, B. S., Helmboldt, C. F., \& Pirozok, R. P. (1967). Small intestinal histopathology of spontaneous capillariasis in the domestic fowl. Avian Diseases, $11,154-169$.

Kajerová, V., \& Baruš, V. (2005). Psittacine birds (Aves: Psittaciformes) as new hosts of Baruscapillaria obsignata (Nematoda: Capillariidae). Acta Veterinaria Brno, 74, 571-574.

Kalinkin, A. L., Makarova, N. I., \& Chumeikin, S. A. (2018). A rare clinical case of tominxosis. The Bulletin of Contemporary Clinical Medicine, 11(3), 89-91.

Kavetska, K. M. (2005). Intestinal nematodes of the Aythyini ducks in Western Pomerania. Wiadomości Parazytologiczne, 51(2), 157-163.

Khalifa, R., \& Othman, R. A. (2014). Some studies on Capillaria philipinensis and its mysterious trip from Philippines to Egypt (review article). Journal of the Egyptian Society of Parasitology, 44(1), 161-171.

Kornaś, S., Basiaga, M., Kowal, J., Nosal, P., Wierzbowska, I., \& Kapkowska, E. (2015). Zatorska goose - a subject of parasitological research. Annals of Parasitology, 61(4), 253-256.

Moravec, F. (1982). Proposal of a new systematic arrangement of nematodes of the family Capillariidae. Folia Parasitologica, 29, 119-132.

Moravec, F., Nagasawa, K., \& Madinabeitia, I. (2010). A new species of Capillaria (Nematoda: Capillariidae) from the intestine of the marine fish Acanthopagrus schlegelii schlegelii (Sparidae) from Japan. Journal of Parasitology, 96(4), 771-774.

Moravec, F., Prokopic, J., \& Shlikas, A. V. (1987). The biology of nematodes of the family Capillariidae Neveu-Lemaire, 1936. Folia Parasitologica, 34, 39-56.

Nakamura, S., \& Asakawa, M. (2001). New records of parasitic nematodes from five species of the Anseriformes in Hokkaido, Japan. Journal of Zoo and Wildlife Medicine, 6, 27-33.

Ochi, A., Hifumi, T., Ueno, T., \& Katayama, Y. (2017). Capillaria hepatica (Calodium hepaticum) infection in a horse: A case report. BMC Veterinary Research, 13(1), 384.

Robles Mdel, R., Bain, O., \& Navone, G. T. (2012). Description of a new Capillariinae (Nematoda: Trichuridae) from Scapteromys aquaticus (Cricetidae: Sigmodontinae) from Buenos Aires, Argentina. Journal of Parasitology, 98(3), 627-639.

Ryzhikov, K. M. (1967). Opredelitel' gel'mintov domashnih vodoplavajushhih ptic [Key to the helminths of domestic water birds]. Nauka, Moscow (in Russian).

Skrjabin, K. I. (1928). Metod polnyh gel'mintologicheskih vskrytij pozvonochnyh, vkljuchaja cheloveka [The method of complete helminthological autopsy of vertebrates, including humans]. Moscow State University, Moscow (in Russian).

Skrjabin, K. I., Shikhobalova, N. P., \& Orlov, I. V. (1957). Osnovy nematodologii. Trihocefalidy i kapilljariidy zhivotnyh i cheloveka i vyzyvaemye imi zabolevanija [Trichocephalids and capillariids of animals and man and the diseases caused by them. The essentials of nematodology]. Russian Academy of Sciences, Moscow (in Russian).

Stapf, A. N., Kavetska, K. M., Ptak, P. P., \& Rzad, I. (2013). Morphometrical and ecological analysis of nematodes of the family Capillariidae (Neveu-Lemaire, 1936) in wild ducks (Anatinae) from the north-western Poland. Annals of Parasitology, 59(4), 195-201. 
Tamaru, M., Yamaki, S., Jimenez, L. A., \& Sato, H. (2015). Morphological and molecular genetic characterization of three Capillaria spp. (Capillaria anatis, Capillaria pudendotecta, and Capillaria madseni) and Baruscapillaria obsignata (Nematoda: Trichuridae: Capillariinae) in avians. Parasitology Research, 114(11), 4011-4022.

Tanveer, S., Ahad, S., \& Chishti, M. Z. (2015). Morphological characterization of nematodes of the genera Capillaria, Acuaria, Amidostomum, Streptocara, Heterakis, and Ascaridia isolated from intestine and gizzard of domestic birds from different regions of the temperate Kashmir valley. Journal of Parasitic Diseases, 39(4), 745-760.

Traversa, D., Di Cesare, A., Lia, R. P., Castagna, G., Meloni, S., Heine, J., Strube, K., Milillo, P., Otranto, D., Meckes, O., \& Schaper, R. (2011). New insights into morphological and biological features of Capillaria aerophila (Trichocephalida, Trichuridae). Parasitology Research, 109(1), 97-104.
Wakelin, D. (1966). The genus Capillaria Zeder, 1800 (Nematoda) in British passerine birds. Parasitology, 56(1), 161-170.

Yevstafyeva, V. A., Stybel, V. V., Sharavara, T. A., Melnychuk, V. V., Yasnolob, I. O., Antipov, A. A., Goncharenko, V. P., \& Bakhur, T. I. (2017). Species-specific morphological characteristics of adult and embryonic Capillaria obsignata roundworms (Nematoda, Capillariidae). Biosystems Diversity, 25(4), 354-360.

Yoshino, T., Uemura, J., Endoh, D., Kaneko, M., Osa, Y., \& Asakawa, M. (2009) Parasitic nematodes of anseriform birds in Hokkaido, Japan. Helminthologia, 46(2), 117-122.

Zd'árská, Z., \& Nebesárová, J. (2000). Bacillary band ultrastructure of the fish parasite Capillaria pterophylli (Nematoda: Capillariidae). Folia Parasitologica, 47(1), 45- 48 . 